\title{
Structure of the southernmost Okinawa Trough from reflection and wide- angle seismic data
}

\author{
Frauke Klingelhoefer ${ }^{a,}{ }^{*}$, Chao-Shing Lee ${ }^{b}$, Jing-Yi Lin $^{a}$ and Jean-Claude Sibuet ${ }^{a}$
}

\author{
a Ifremer, Department of Marine Geosciences, BP 70, 29280 Plouzané cedex, France \\ ${ }^{b}$ Institute of Applied Geophysics, National Taiwan Ocean University, 2 Pei-Ning Road, Keelung 202, Taiwan
}

*: Corresponding author : Frauke Klingelhoefer, Tel.: +33 2982242 21; fax: +33 29822 45 49, email address : Frauke.Klingelhoefer@ifremer.fr

\begin{abstract}
:
During a passive seismic experiment in the Okinawa Trough the shots of two reflection profiles were recorded by ocean bottom seismometers (OBS). Both profiles include 3 ocean-bottom instruments, are about $65 \mathrm{~km}$ in length and located in the axial portion of the southwestern Okinawa Trough. Processing of the reflection seismic data images recent deformation of the sedimentary units. Forward modelling of the wide-angle data on both profiles reveals a 1-2 km thick sedimentary infill overlying an acoustic basement characterised by seismic velocities between 3.2 and $3.5 \mathrm{~km} / \mathrm{s}$. Crustal thickness could only be modelled on one profile and was determined to be around $10 \mathrm{~km}$, thickening towards the Ryukyu Arc in the south. Gravity modelling was used to additionally constrain both profiles especially the deep structure of Profile 1.
\end{abstract}

Keywords: Okinawa Trough; Wide-angle seismics; Crustal structure; Back-arc basin

\section{Introduction}

The Okinawa Trough, bounded by the Ryukyu Arc to the south and east and by the East China Sea continental shelf to the north and west, is a curved backarc basin, located behind the Ryukyu trencharc system (Fig. 1). Its maximum depth $(2300 \mathrm{~m})$ is located to the south and decreases to only $200 \mathrm{~m}$ towards the north, close to Japan. It formed by extension either of continental lithosphere (Uyeda, 1977) or of continental lithosphere previously intruded by arc volcanism (Sibuet and Hsu, 1997). Sibuet and Hsu (1997) proposed, that the series of continental shelf basins located parallel to the mainland China shoreline consist of several belts of backarc basins separated by relic arcs. The Okinawa Trough in this case represents an active backarc basin formed by extension of a continental crust which contains an unknown proportion of arc material. From Kyushu to Okinawa Island subaerial active volcanoes coincide with the Ryukyu arc (Sibuet et al., 1998). Southwest of Okinawa Island, the volcanic front moves progressively into the Okinawa Trough and consists of a series of seamounts which ends close to Taiwan in Kueishantao Island (Sibuet et al., 1998).

Five other belts of basins corresponding to five different rifting phases were identified in the East China Sea (Sibuet and Hsu, 1997). They are mostly oriented NE-SW and their tectonic history shows that rifting occurred between late Cretaceous/early Paleocene and middle Miocene (Sibuet and Hsu, 1997). In the Okinawa Trough, rifting probably started in middle Miocene (Letouzey and Kimura, 1986). 
During one of the first wide-angle seismic studies carried out in the Philippine Sea area, three regional seismic transects were acquired (Murauchi et al., 1968). On the basis of these refraction seismic measurements, Murauchi et al. (1968) deduced, that the crust underlying the Okinawa Trough is generally similar to that of continental crust. They found a Moho depth of $12 \mathrm{~km}$ in the eastern Okinawa Trough rapidly thinning towards the northwest (Figure 1). From reflection seismic data the sedimentary and upper crustal velocities were determined by Ludwig et al., (1973) in the northern Okinawa Trough around $31^{\circ} \mathrm{N}$ and Leyden et al. (1973) correlated offshore refraction velocities with onland drilling and refraction data to propose a crustal structure in the Okinawa Trough. Based on models from wide-angle seismic data, Hagen et al. (1988) propose the nature of the crust east of Taiwan and south of the Ryukyu Trench to be oceanic and continental north of the trench, close to our study area (Figure 1). Moho depth in the continental part of the model is around $12-14 \mathrm{~km}$ deepening towards the south.

Lee et al. (1980) using two ship seismic refraction lines, found that the Okinawa trough is underlain by a roughly 9 $\mathrm{km}$ thick crust, which is overlain by an acoustic basement layer and a 1-2 km thick layer of sediments (Figure 1 inset). During the TAICRUST survey combined reflection and wide-angle seismic profiles were acquired in southwestern Ryukyu subduction zone (Figure 1 inset). Profile 1 of this experiment, extends from the southern Okinawa Trough, close to our study area, over the Ryukyu Arc, the Nanao Forarc Basin, the Yaeyama Accretionary Ridge, the Ryukyu Trench into the Huatung Basin (Wang et al., 2001; Wang et al., 2004). 8 OBS (Ocean Bottom Seismometers) were deployed, on this $300 \mathrm{~km}$ long profile. Forward modelling and tomography of these data yielded a Moho depth of 22 km underneath the Ryukyu Arc, rising towards the Okinawa Trough (Wang et al., 2001; Wang et al., 2004).

Higher crustal thicknesses of up to $20-23 \mathrm{~km}$ are found in the northernmost Okinawa Trough (Nakahigashi et al., 2004). A regional velocity model has been constructed using available datasets and applied to reduce the relocation error of local earthquakes (Font et al., 2003). Large-scale velocity models from earthquake tomography image the subducting slab in the upper mantle (Lallemand et al., 2001; Nakamura et al., 2003; Hsu, 2001).

During the 2003 Okinawa Trough cruise performed on the Ocean Researcher 1 vessel, two reflection seismic profiles were shot along aligned ocean bottom seismometers (OBS) which were deployed to record earthquake data. The main aim of the marine experiment was the acquisition of passive seismological data in order to constrain the deep crustal and mantle structure in the region of an inferred tear of the Ryukyu slab (Lin et al., 2004b; Lin et al., 2004a). Results from inversion of the seismological data are described by Lin et al. (this volume). The reflection 
and wide-angle seismic data presented in this paper provide information on the sedimentary and crustal velocity structure at a much higher resolution than the models established from seismological data. Both models are therefore complimentary and presented in separate papers.

\section{Data Acquisition, quality and processing}

The two reflection seismic profiles presented in this paper were shot along the ocean-bottom instruments using a 600 m-long 12 channel streamer and a 1275 inch $^{3}$ airgun array (Figure 1). Each of the two profiles modelled in this study used three ocean-bottom seismometers of the Ifremer OBS pool. All instruments are equipped with a 3-component externally deployed geophone and one hydrophone (auf, ).

Because the main aim of this cruise was the recording of the natural seismicity in the Okinawa Trough during 12 days, the interval between OBS stations was chosen to be about $20 \mathrm{~km}$, and not specifically designed for for wideangle seismic experiments. The active seismic shots served two purposes: first to allow an exact relocation of the OBS position and second the acquisition of reflection seismic data using a streamer. Analyses of active source data on the two profiles and the reflection seismic data allowed us to determine the geometry of the sedimentary and upper crustal layers in the trough. Although the number of instruments per profile was small and the reflection seismic data are of only fair quality, these data present substantial additional constraints on the crustal structure in this area where

deep seismic data is otherwise scarce. They also provide complimentary information to the lower resolution velocity models from the passive seismic experiment Lin et al., (this volume).

Processing of the multi-channel seismic data included spherical divergence correction, bandpass filtering (filter corner frequencies: 3-5,60-120 Hz), normal move-out correction and stack (Figure 2). An automatic gain control was applied after the stack. The shallow sedimentary layers are well imaged in the seismic reflection section and the accoustic basement reflector is distinguishable in regions of low sediment thickness.

Pre-processing of the OBS data included calculation of the clock-drift corrections (between 2 and 5 ms per day) to adjust the clock in each instrument to the GPS base time. Instrument locations were corrected for drift from the deployment position during their descent to the seafloor using the direct water wave arrival. Picking of the onset of first and secondary arrivals was performed without filtering where possible. Different filters were applied to the instruments where necessary, depending on the quality of the data and offset to the source. Data quality of the 3 
instruments on Profile 2 is good with deep arrivals from the crust-mantle boundary and the upper mantle on all three instruments (Figure 3). The data quality located on Profile 2 is generally good, with clearly visible deep arrivals from the crust-mantle boundary on all three instruments (Figure 3). On Profile 1 the data quality is much lower and no crustal or mantle arrivals could be identified on all three instruments.

\section{Velocity and gravity modelling}

The data were modelled using the inversion and ray tracing algorithm RAYINVR (Zelt and Smith, 1992). Modelling was performed using a layer-stripping approach, proceeding from the top of the structure towards the bottom. The upper layers in the model, not constrained by arrivals from within the same layer, were adjusted to improve the fit of arrivals from lower layers. We used a two-dimensional iterative damped least-squares inversion of travel times (Zelt and Smith, 1992). Arrival times of the main sedimentary layers and basement were picked from the reflection seismic data where possible. The arrival times were converted to depth using the OBS data and velocities consistent with those from velocity analysis of the reflection seismic data. The depth and velocities of the crustal layers and the upper mantle were modelled from the OBS data only. Based on the data quality the picking uncertainties were taken to be $50 \mathrm{~ms}$ for the direct water arrivals and $100 \mathrm{~ms}$ for all other arrivals.

The Profile 2 velocity model is comprised of 6 layers: the water layer, one sedimentary layer, one underlying acoustic basement layer, two crustal layers and the upper mantle layer (Figure 4). Each layer is defined by depth and velocity nodes. The water velocity is found to be $1500 \mathrm{~m} / \mathrm{s}$ from modelling, which agrees with existing water velocity data from oceanographic measurement compilations (Dietrich et al., 1975). The seafloor bathymetry was taken from a bathymetric map of the Okinawa Trough, produced from a new grid (grid spacing $150 \mathrm{~m}$ ) and including all available swath bathymetric data from French and Japanese oceanographic ships (Sibuet et al., 2004b). The seafloor model layer includes depth nodes at a spacing of $1.5 \mathrm{~km}$ (Figure 4). The sedimentary layer is modelled using the reflection seismic data for layer geometry converted to depth using velocities from the OBS data and sampled at the the same node spacing as the seafloor layer. Sediment velocities range from $1.9 \mathrm{~km} / \mathrm{s}$ to $2.1 \mathrm{~km} / \mathrm{s}$. The acoustic basement layer displays velocities between 3.2 and $3.5 \mathrm{~km} / \mathrm{s}$. The top of the crust has also been modelled with a node spacing of 2.5 $\mathrm{km}$, as it is not well resolved everywhere on the profile in the reflection seismic data. The crust is modelled by two layers of 4.5 to $5.6 \mathrm{~km} / \mathrm{s}$ and 5.6 to $7.0 \mathrm{~km} / \mathrm{s}$. The lower-crustal layer and the Moho are imaged at a lower resolution. 
Thus we use a depth node spacing of $10 \mathrm{~km}$. No arrivals from the upper mantle have been modelled so a constant gradient was assumed from $8.0 \mathrm{~km} / \mathrm{s}$ to $8.2 \mathrm{~km} / \mathrm{s}$ throughout the model for gravity modelling (Figure 4).

As no deep arrivals could be used to constrain the deeper velocity structure on Profile 1, a similar deep crustal structure and Moho depth as found in Profile 2, have been assumed to model Profile 1 (Figures 5 and 4). The deep part of this model is thus constrained by gravity modelling only. Sedimentary velocities range from 1.9 to $2.1 \mathrm{~km} / \mathrm{s}$ and the acoustic basement from 3.2 to $3.5 \mathrm{~km} / \mathrm{s}$. The seismic velocities and geometry of the two crustal layers have been adopted from Profile 2 and adjusted using gravity modelling (Figure 4).

The fit between predicted arrival times and travel time picks provides information about the quality of the model (Figures $5(\mathrm{~d})$ and $4(\mathrm{~d})$ ). The $\chi^{2}$-error is defined as the root-mean-square (rms) traveltime misfit between observed and calculated arrivals normalised to the picking uncertainty. As the $\chi^{2}$-error depends on the traveltime misfit as well as on the assigned picking error, it can exhibit a large value for smaller travel-time misfit for phases of high quality. The number of picks, the RMS travel-time residual and the $\chi^{2}$-error for all phases are listed in Tables 1 and 2 . In the final model the $\chi^{2}$-error of every phase is close to 1 , characteristic for a good fit without over-interpretation of phases with high signal/noise ratio. This ensures that the final models represent the minimum constrained structure.

Assuming seismic velocities and densities can be correlated, gravity modelling provides important additional constraints on the seismic model. Areas not imaged by the seismic rayscan be modelled by comparing calculated gravity anomalies with those observed. Gravity anomalies along the profiles were extracted from the satellite derived free-air gravity grid of Sandwell and Smith (1995). The gravity data were forward modelled using the GRAVMOD software (Zelt and Smith, 1992). Seismic velocities were converted to densities using the relationship of Ludwig (1970) . The upper mantle densities were set to a constant $3.32 \mathrm{~g} / \mathrm{cm}^{3}$. To avoid edge effects, both models were extended by $100 \mathrm{~km}$ at both ends and down to a depth of $95 \mathrm{~km}$. Both profiles show a good agreement between the predicted and measured gravity anomalies (Figure 5a and 4a). However, as the deep structure of Profile 1 is not constrained by seismic data, it has been modelled using the gravity data.

\section{Results and Discussion}

Both wide-angle seismic profiles from the Okinawa Trough show sedimentary layers of up to $1 \mathrm{~km}$ thickness in the middle of the trough. These overlie a layer representing the acoustic basement, with velocities between 3.2 and 3.5 
$\mathrm{km} / \mathrm{s}$. Based on its velocity and the high impedance contrast to the overlying sedimentary layer we suggest that this layer might include some limited amount of backarc volcanism or arc relics emplaced during formation of older backarc basins since early Tertiary (Sibuet and Hsu, 1997) together with compacted sediments. A two layered crustal model with a higher velocity gradient in the upper crust fits the data better than a one layer model. However, as no reflection from the middle of the crust can be identified in the data, no velocity step is modelled between both layers, and the interface therefore represents a second order boundary. Lower layer velocities and Moho depth are only constrained by seismic data on Profile 2 . The total crustal thickness is 8 to $9 \mathrm{~km}$ in the middle of the trough and thickens to about $10 \mathrm{~km}$ towards the Ryukyu arc.

The crustal thickness of $8 \mathrm{~km}$ found on profile 2 could be explained by either normal oceanic crust or thinned continental crust. A comparison of the seismic crustal velocities from this study with those of normal oceanic crust (White et al., 1992) indicates that velocities and velocity gradients are lower than in normal oceanic crust (Figure 6 b) and that the crust of the Okinawa trough is definitely not oceanic. The lower velocity gradients and velocities, however are in good agreement with thinned continental crust. Although the OBS spacing is too large to offer a more detailed resolution, the slightly elevated lower crustal velocities of up to $7 \mathrm{~km} / \mathrm{s}$ compared to continental crust might be caused by arc volcanic intrusions into the lower crust during extension as suggested by Sibuet and Hsu, 2004.

The sedimentary and crustal velocities found from ray-tracing agrees well with values from previous work (Figure 6 a). The Moho depth modelled from OBS data by Hagen et al. 1988 is about 1.5 kilometers deeper than found in this study and lies therefore within the error limit of the two models which are both characterised by a large OBS interval. The Moho depth found by Lee et al. (1980) is slightly deeper than in this study, a fact which might be explained by the location of the profile slightly further east and the method of data processing. The velocity model from the TAICRUST (Wang et al., 2001; Wang et al., 2004) experiment to the south of our study area on the Ryukyu arc show larger crustal thickness, which is in good agreement with the thickening of the crust in our velocity models towards the south.

The MCS profiles image the shallow crustal structure, in particular recent deformation of the sedimentary units (Figure 2). A series of normal fauls are observed in the deepest portion of the Okinawa Trough affecting the most superficial (most recent) sediments. On Profile 2 an uplifted horst block bounds the southern side and is separated from the basin by a major $\mathrm{N}$ dipping normal fault. The top basement boundary is also offset by the major normal faults. Although both $\mathrm{N}$ and $\mathrm{S}$ dipping normal fauls are observed, the basin is flanked primarily by $\mathrm{N}$ dipping faults 
on its $\mathrm{S}$ boundary and conversely $\mathrm{S}$ dipping faults on its $\mathrm{N}$ boundary, consistent with ongoing extension through block faulting.

The thin crust found from wide-angle seismic modelling as well as the normal faulting imaged in the reflection seismic profiles originate from the high extension of the crust in the axis of the trough. A layer with velocities between 3 and $3.5 \mathrm{~km} / \mathrm{s}$ which acts as an acoustic basement underneath the sedimentary layer might be composed of a mixture of volcanic products and sediments.

\section{Acknowledgments}

We thank Y. Auffret, P. Pelleau and J. Crozon for their help with the data acquisition. We also thank the Captain and the crew of the Ocean Researcher 1 for their work at sea. The SISBISE software was used for the reflection seismic data processing and the SEISMIC UNIX software for processing of the OBS data (Stockwell, 2003). Many thanks also to E. Cosquer for patient explanations regarding the reflection seismic data processing. The GMT software (Wessel and Smith, 1995) was used to generate several figures.

\section{References}

Dietrich, G., Kalle, K., Krauss, W., and Siedler, G. (1975). Allgemeine Meereskunde. Bortraeger, Berlin, pages 259-264.

Font, Y., Kao, H., Liu, C.-S., and Chiao, L.-Y. (2003). A comprehensive 3D seismic velocity model for the eastern Taiwan-southernmost Ryukyu regions. Terr. Atm. Oc. Sci., 14, pages 159-182.

Hagen, R. A., Duennebier, F. K., and Hsu, V. (1988). A seismic refraction study of the crustal structure in the active seismic zone east of Taiwan. J. Geophys. Res., 93 (B5), pages 4785-4796.

Hsu, S.-K. (2001). Subduction/collision complexities in the Taiwan-Ryukyu junction area: Tectonics of the northwestern corner of the Philippine Sea Plate. Terr. Atm. Oc. Sci., Suppl. S : 209-230, pages 1017-0839. 
Lallemand, S., Font, Y., Bijwaard, H., and Kao, H. (2001). New insights on 3-D plates interaction near Taiwan from tomography and tectonic implications. Tectonophysics, 335, pages 229-253.

Lee, C.-S., Shor, G. G., Bibee, L. D., Lu, R. S., and Hilde, T. W. C. (1980). Okinawa Trough: Origin as backarc basin. Mar. Geology, 35, pages 219-241.

Letouzey, J. and Kimura, M. (1986). The Okinawa Trough: Genesis of a back-arc basin developing along a continental margin. Tectonophysics, 125, pages 209-230.

Leyden, R., Ewing, M., and Murauchi, S. (1973). Sonobuoy refraction measurements in East China Sea. Am. Assoc. Pet. Geol. Bull. 57 (12), pages 2396-2403.

Lin, J.-Y., Hsu, S.-K., and Sibuet, J.-C. (2004a). Melting features along the western Ryukyu slab edge (northeast Taiwan) and Ryukyu slab tear (southernmost Okinawa Trough): Tomographic evidence. J. Geophys. Res., 109, B12402, page doi:10.1029/2004JB003260.

Lin, J.-Y., Hsu, S.-K., and Sibuet, J.-C. (2004b). Melting features aong the Ryukyu slab tear, beneath the southwestern Okinawa Trough. Gephys. Res. Lett., 31, L19607, page doi:10.1029/2004GL020862.

Ludwig, W. J., Den, N., and Murauchi, S. (1973). Seismic-reflection measurements of southwest Japan margin. J. Geophys. Res., 78, pages 2508-2515.

Ludwig, W. J., Nafe, J. E., and Drake, C. L. (1970). Seismic refraction. in: The Sea, ed. Maxwell, A. E., Wiley, New York, pages 53-84.

Murauchi, S., Den, N., Asano, S., Hotta, H., Yoshii, T., Asanuma, T., Hagiwara, K., Ichikawa, K., Sato, T., Ludwig, W. J., Ewing, J. I., Edgar, N. T., and Houtz, R. E. (1968). Crustal structure of the Philippine Sea. J. Geophys. Res., 73, pages 3143-3171.

Nakahigashi, K., Shinohara, M., Suzuki, S., Hino, R., Shiobara, H., Takenaka, H., Nishino, M., Sato, T., Yoneshima, S., and Kanazawa, T. (2004). Seismic structure of the crust and uppermost mantle in the incipient stage of back arc rifting-northernmost Okinawa Trough. Geophys. Res. Lett., 31, page doi:10.1029/2003GL018928.

Nakamura, M., Yoshida, Y., Zhao, D. P., Katao, H., and Nishimura, S. (2003). Three-dimensional P- and S-wave velocity structures beneath the Ryukyu arc. Tectonophysics 369 (3-4), pages 121-143. 
Sandwell, D. and Smith, W. (1995). Marine gravity from satellite altimetry. The Geological Data Center, Scripps Institution of Oceanography, La Jolla, CA92093 (digital file, version 7.2), (anonymous ftp to baltica.ucsd.edu).

Sibuet, J.-C., Deffontaines, B., Hsu, S.-K., Thareau, N., Le Formal, J.-P., and Liu, C.-S. (1998). The southwestern Okinawa Trough backarc basin: Tectonics and volcanism. J. Geophys. Res., 103(B12), pages 30245-30267.

Sibuet, J.-C. and Hsu, S.-K. (1997). Geodynamics of the Taiwan arc-arc collision. Tectonophysics, 274, pages 221251.

Sibuet, J.-C., Hsu, S.-K., and Debayle, E. (2004a). Geodynamic context of the Taiwan orogen. American Geophysical Union monograph 149, Ocean-Continent Interactions in the East Asian Marginal Seas, Edited by P. Clift, P. Wang, W. Kuhnt and D. Hayes, pages 127-158.

Sibuet, J.-C., Hsu, S.-K., and Normand, A. (2004b). Tectonic significance of the Taitung Canyon, Huatung Basin, east of Taiwan. Mar. Geophys. Res. 25 (1-2), pages 98-107.

Stockwell, J. W. (2003). The CWP/SU: Seismic Unix Release 37: a free package for seismic research and processing. Center for Wave Phenomena, ColoradoSchool of Mines.

Uyeda, S. (1977). Some basic problems in trench-arc-back-arc-system. Island arcs, Deep Sea Trenches and Back Arc Basins, Maurice Ewing Ser., ed. by M. and W. C. Pitman, Am. Geophys. Union, pages 1-14.

Wang, T. K., Lin, S.-F., Liu, C.-S., and Wang, C.-S. (2004). Crustal structure of the southernmost Ryukyu subduction zone: OBS, MCS and gravity modelling. Geophys. J. Int., 157, pages 147-163.

Wang, T. K., McIntosh, K., Nakamura, Y., Liu, C.-S., and Chen, H.-W. (2001). Velocity-interface structure of the southwestern Ryukyu subduction zone from EW9509-1 OBS/MCS data. Mar. Geophys. Res. 22 (4), pages 265287.

Wessel, P. and Smith, W. H. F. (1995). A new version of the Generic Mapping Tool (GMT). EOS, Trans. Am. Geophys. Union, 76, page 329.

White, R. S., McKenzie, D., and O'Nions, R. (1992). Oceanic crustal thickness from seismic measurements and rare earth element inversions. J. Geophys. Res., 97, pages 19,683-19,715. 
Zelt, C. A. and Smith, R. B. (1992). Seismic travel time inversion for 2-D crustal velocity structure. Geophys. J. Int. 108 , pages $16-31$. 


\begin{tabular}{rccc}
\hline Phase & Nr. of picks & RMS traveltime residual & chi-squared \\
\hline \hline Water & 254 & 0.062 & 1.528 \\
Sediments & 102 & 0.072 & 0.518 \\
Sediments reflection & 69 & 0.071 & 0.508 \\
Crust & 95 & 0.064 & 0.413 \\
\hline All Phases & 520 & 0.066 & 0.987
\end{tabular}

Table 1: Traveltime residuals and chi-squared error for all phases and the complete model of Profile 1.

\begin{tabular}{rccc}
\hline Phase & Nr. of picks & RMS traveltime residual & chi-squared \\
\hline \hline Water & 238 & 0.056 & 1.248 \\
Sediments & 20 & 0.063 & 0.415 \\
Sediments reflection & 168 & 0.125 & 1.577 \\
Crust & 735 & 0.055 & 0.306 \\
Basement reflection & 39 & 0.118 & 1.433 \\
Lower crust & 106 & 0.067 & 0.450 \\
PmP & 84 & 0.060 & 0.361 \\
\hline All Phases & 1390 & 0.071 & 0.665
\end{tabular}

Table 2: Traveltime residuals and chi-squared error for all phases and the complete model of Profile 2. 


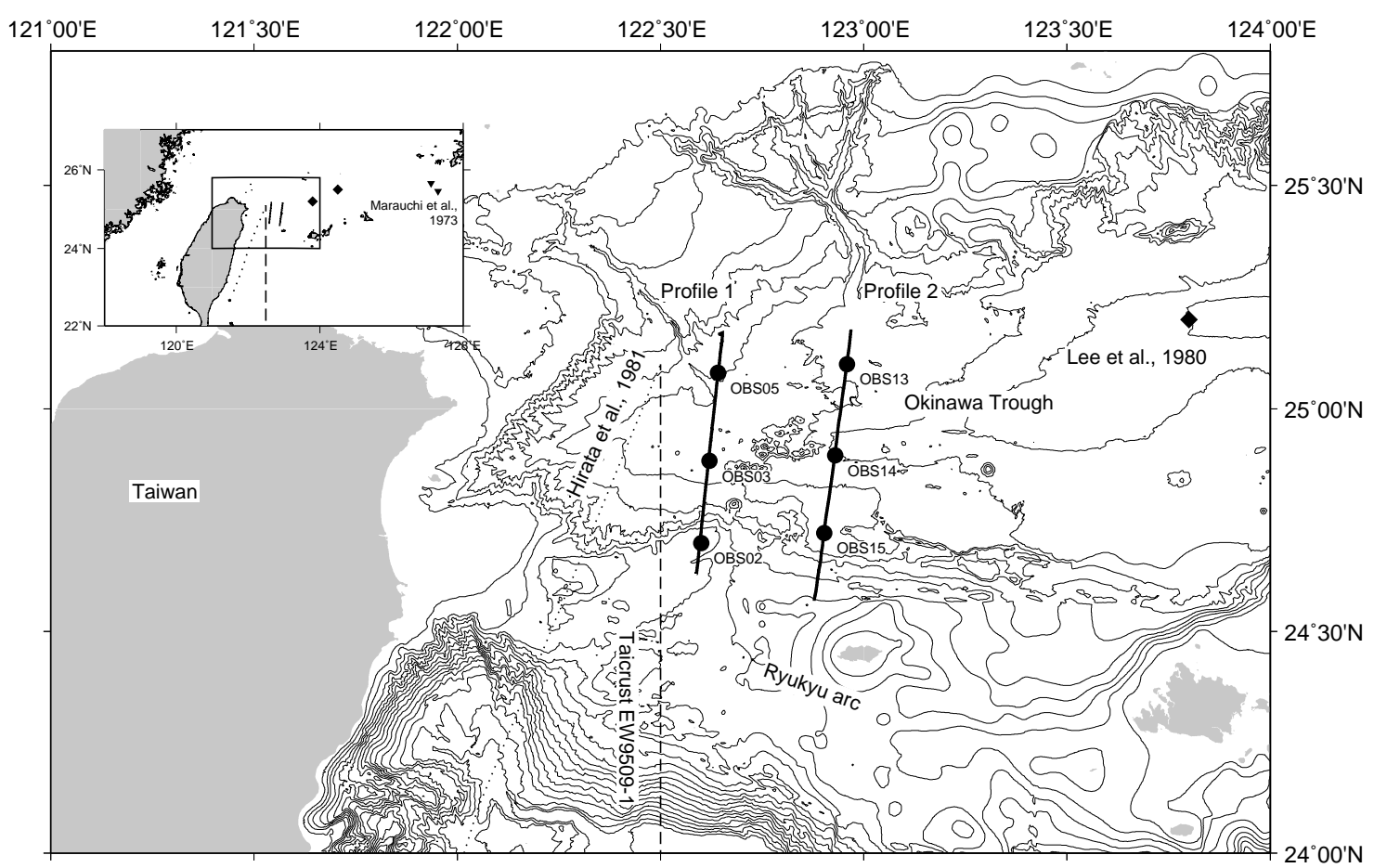

Figure 1: Contoured seafloor bathymetry of the study region (Sibuet, unpublished data). OBS positions are marked by black circles and the two black lines mark the two profiles from this study. Black diamonds mark receiving ship position from Lee et al., 1980, black dotted line the OBS profile from Hagen et al., 1988 and black broken line Profile 1 from the TAICRUST experiment (Wang et al., 2001; Wang et al., 2004). Inset: location of the study area. Inverted triangles mark refraction measurement positions from Murauchi et al., 1973 

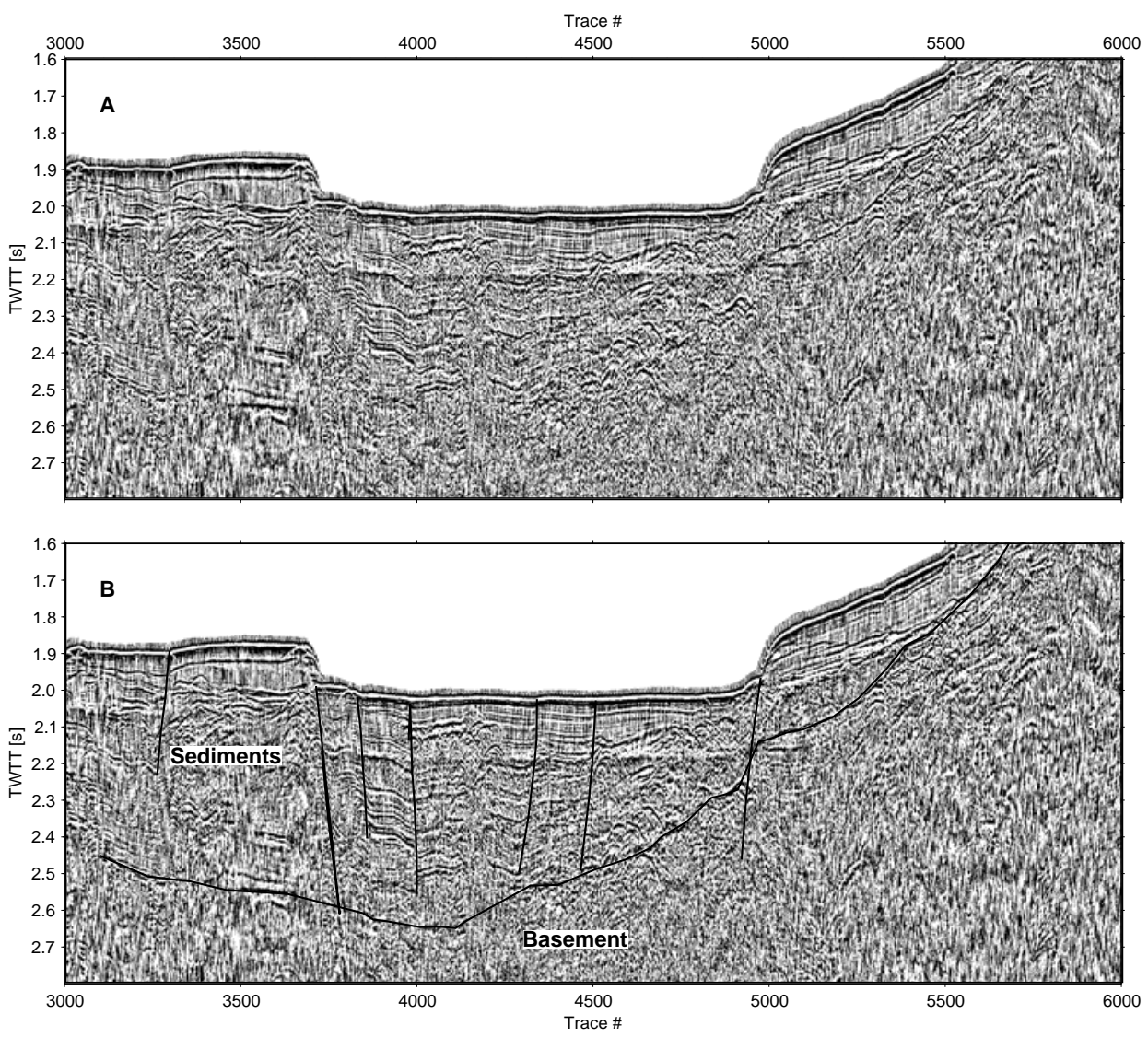

Figure 2: (A) Part of reflection seismic Profile 2 crossing the Okinawa Trough. The data are bandpass filtered, stacked and migrated. An automatic gain control has been applied. (B) Interpretation of the reflection seismic section. 

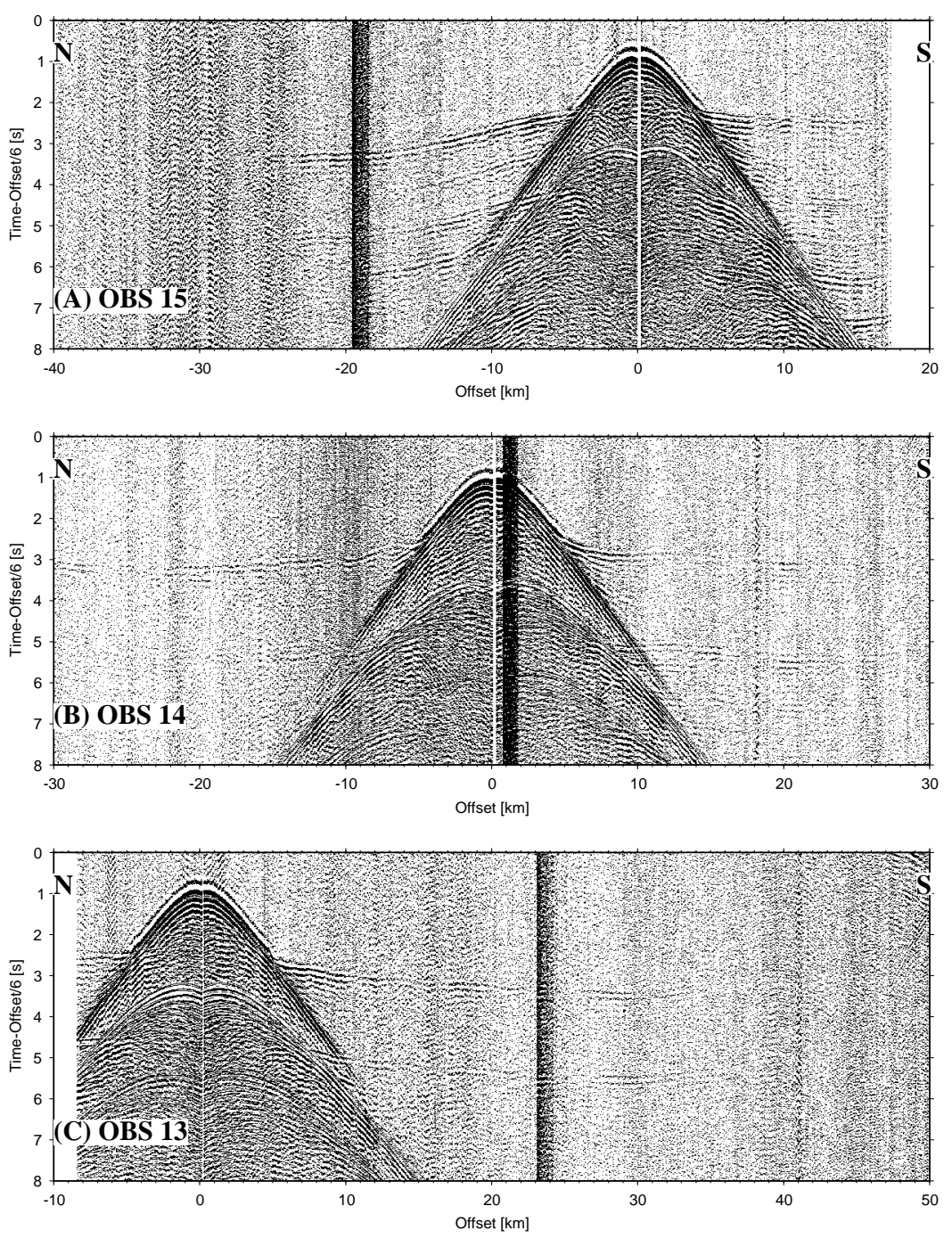

Figure 3: (A) Bandpass (3-5, 48-72) Hz) filtered vertical geophone data from OBS 15. The data are gain-adjusted according to offset and reduced to a velocity of $6 \mathrm{~km} / \mathrm{s}$. (B) Data from OBS 14 processed as in (A). (C) Data from OBS 13 processed as in (A). 

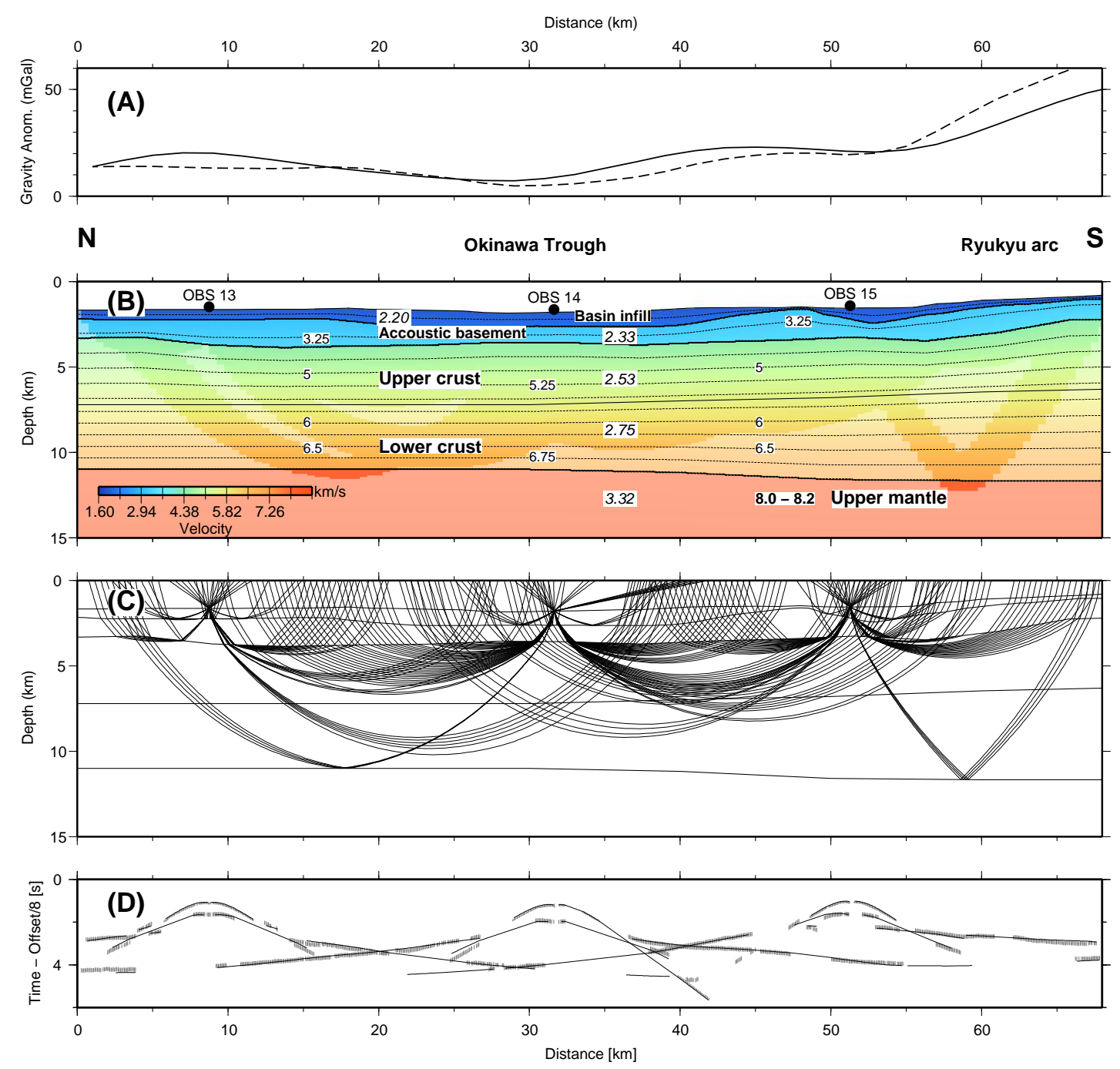

Figure 4: (a) Gravity anomaly from satellite altimetry (Sandwell and Smith, 1995) (broken black line) and predicted gravity anomaly from conversion of the seismic velocities to densities. (b) Final velocity model of Profile 2 including the model boundaries (solid lines) and iso-velocity contours every $0.25 \mathrm{~km} / \mathrm{s}$. OBS locations are marked by black circles. Mean layer densities used for gravity modelling are anontated in italic. (c) Ray coverage of Profile 1 with every 5 th ray plotted. (d) fit between the travel time picks (dark grey bars) and the predicted arrival times (black lines) from ray-tracing. 

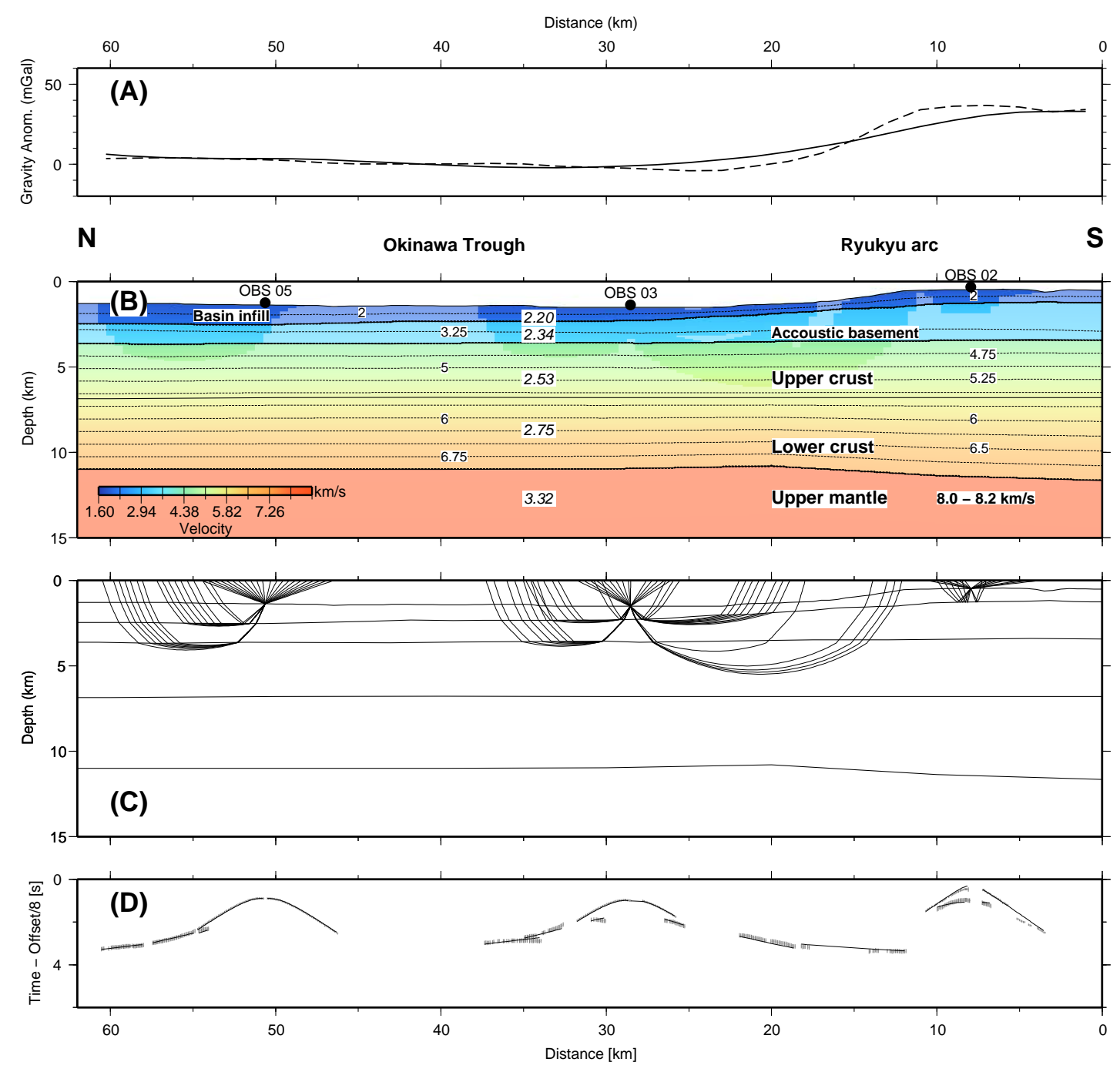

Figure 5: (a) Gravity anomaly from satellite altimetry (Sandwell and Smith, 1995) (broken black line) and predicted gravity anomaly from conversion of the seismic velocities to densities. (b) Final velocity model of Profile 1 including the model boundaries (solid lines) and iso-velocity contours every $0.25 \mathrm{~km} / \mathrm{s}$. OBS locations are marked by black circles. Mean layer densities used for gravity modelling are anontated in italic. (c) Ray coverage of Profile 2 with every 5 th ray plotted. (d) fit between the travel time picks (dark grey bars) and the predicted arrival times (black lines) from ray-tracing. 

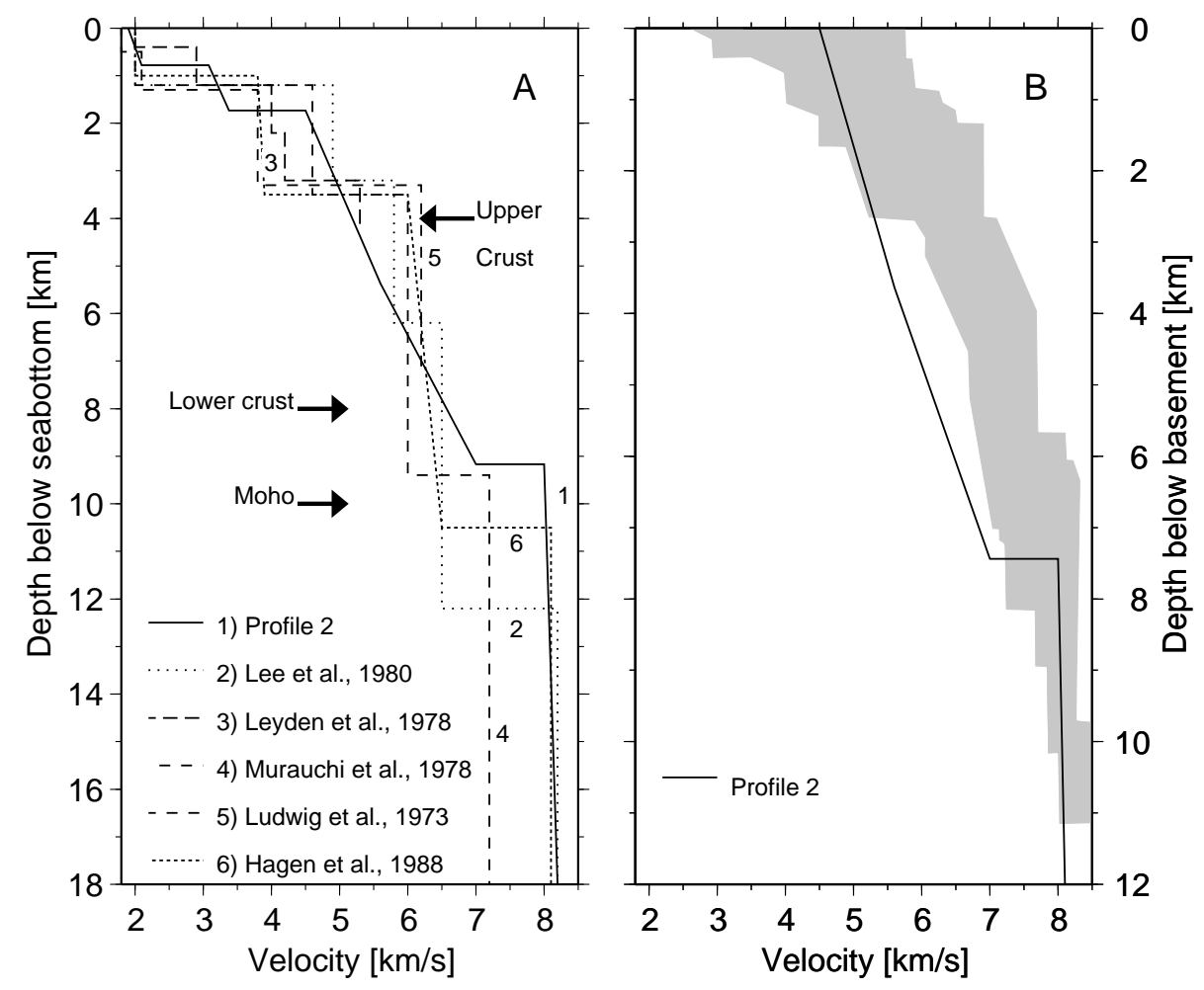

Figure 6: (A) Comparison of different velocity-depth profiles from the Okinawa Trough. (1) this study (2) Lee et al., 1980 (3) Leyden et al., 1973 (4) Murauchi et al., 1968 (5) Ludwig et al., 1973 (6) Hagen et al., 1988 (B) Crustal velocity-depth function from profile 2. Grey shaded area marks velocity bounds for oceanic crust (White et al., 1992). 